\title{
Economic Analysis of Pea (Pisum sativum) in Himachal Pradesh
}

\author{
Navneet Singh*, Ravinder Sharma and Ratika Kayastha
}

Department of Social Sciences, Dr Y S Parmar University of Horticulture \& Forestry, Solan, Himachal Pradesh, India

*Corresponding author: kharangranavneet@gmail.com (ORCID ID: 0000-0003-4306-7646)

Received: 24-12-2019

Revised: $13-04-2020$

Accepted: 23-05-2020

\begin{abstract}
The study was conducted in Solan district of Himachal Pradesh to analyze the economics of pea cultivation at different farm size category. The study reveals that total cost of cultivation of pea production was ₹ 84699.37 per hectare. Out of which cost A1, A2, B1, B2, C1, C2, and C3 were ₹ 44150.67, ₹ 44150.67, ₹ 45135.52, ₹ 57521.56, ₹ 64613.39, ₹ 76999.43 and ₹ 84699.37 respectively. The cost of cultivation of pea in case of marginal farms was higher as compared to different farm size category. The total yield of pea production was 72.16 quintals per hectare. The total returns and net returns from pea production were ₹ 144324.32 and ₹ 59624.95 per hectare, respectively. The total returns and net returns from pea in case of large farms were higher as compared to different farm size category.

\section{Highlights}

(0 The cost of cultivation of pea in case of marginal farms was higher as compared to different farm size category whereas total returns and net returns from pea in case of large farms were higher as compared to different farm size category.
\end{abstract}

Keywords: Pea, Cost of cultivation and Returns, Himachal Pradesh

The potential of vegetables in contributing to the national economy has been well recognized in recent years. India ranks second in the area as well as production of pea next to China. In spite of that, this seemingly high level of production can provide only 208 grams of vegetables per capita (Sharma, 2003), as against the suggested dietary intake of $275 \mathrm{~g}$ and $250 \mathrm{~g}$ per capita per day for adult male and female, respectively for undertaking moderate work (Swaminathan, 2002). The total area, production and productivity of pea in India in 2017-18 was 540.48 thousand Ha, 5422.14 thousand MT and 10.0 MT/ ha respectively (Anonymous, 2018). The major pea growing states are Uttar Pradesh, Madhya Pradesh, Jharkhand, Punjab, Himachal Pradesh, West Bengal, Haryana, Bihar, Uttarakhand, Orissa and Karnataka. Himachal Pradesh is $5^{\text {th }}$ leading pea producing state of India with total production of 294.96 thousand metric tonnes during the year 2017-18 (Anonymous, 2018).

Pea is small spherical seed or pod of fruit Pisum sativum and belongs to leguminaceae family along with beans and peanuts. It was one of the first plants cultivated by humans and remains an important food crop today. The pea is native to western Asia and North Africa. Wild peas can still be found in Afghanistan, Iran, and Ethiopia (Oelke 1991).

Peas, like many legumes, contain symbiotic bacteria called Rhizobia within root nodules of their root systems. These bacteria have the special ability of fixing nitrogen from atmospheric, molecular nitrogen $\left(\mathrm{N}_{2}\right)$ into ammonia $\left(\mathrm{NH}_{3}\right)$. It contains high

How to cite this article: Singh, N., Sharma, R. and Kayastha, R. (2020). Economic analysis of pea (Pisum sativum) in Himachal Pradesh. Economic Affairs, 65(2): 191-195.

Source of Support: None; Conflict of Interest: None (c) 9 
percentage of digestible proteins, vit-A and vit-C, rich in minerals like $\mathrm{Ca}$ and $\mathrm{P}$.

Peas cultivation is highly labour-intensive like all other vegetable crops and requires high dosages of manures and fertilizers (Rao and Tripathi 1979; Khunt and Desai 1996). The main constituent of the cost of cultivation of peas is manures and fertilizers, followed by cost on bullock/ human labour/tractor and pesticides/chemicals. Thakur et al. (1994) observed that the income per hectare from vegetable crops has been almost four-times, as compared to that from food crops. Thus, the farmers should have to be motivated to diversify to more remunerative cropping patterns like vegetable cultivation instead of the traditional, less profitable ones (Singh 1995). Similar types of results were reported by (Sharma et al. 2000; Maurya et al. 2001).

The objective of my study was to study the cost of cultivation of this most important cash crop among vegetables.

\section{MATERIALS AND METHODS}

The study was conducted in Solan district of Himachal Pradesh. This area was selected because of its significant contribution with respect to area and production of vegetable crops in the state and simultaneously providing fruitful employment to the families involved in vegetable cultivation.

Multistage random sampling was adopted to select the ultimate sample of the respondents i.e. the vegetable growers.

(a) At the first stage, 2 blocks i.e. Kandaghat and Solan out of 5 blocks were selected.

(b) At the second stage, a list of villages growing vegetables in the selected blocks were prepared and 5 villages from each block were randomly selected.

(c) At the third stage, list of vegetable growers of the selected villages was prepared and a sample of 10 vegetable growers in each selected village were selected for collection of primary data. Thus the total sample consisted of 100 respondents.

A pre-tested structured interview schedule was prepared. Data was collected by personal interview method. For the analysis of data the total vegetable growers were divided into four classes according to the size of their land holdings, viz., marginal $(<1 \mathrm{ha})$, small (1-2 ha), medium (2-4 ha) and large farmers ( $>4$ ha).

\section{Analytical Tools}

\section{Cost of cultivation}

The cost of cultivation of vegetables crops was worked out by using various cost concepts defined below:

Cost $\mathbf{A}_{1}$ : It includes:

(a) Cost of hired human labour

(b) Cost of owned machinery

(c) Cost of hired machinery

(d) Cost of fertilizer

(e) Cost of manure

(f) Cost of seed (owned / purchased)

(g) Cost of plant protection chemicals

(h) Land revenue

(i) Depreciation of farm machinery, equipments and farm buildings

(j) Interest on owned working capital

Cost $A_{2}$ : Cost $A_{1}+$ Rent paid for leased in land

Cost $B_{1}$ : Cost $A_{1}+$ Interest on owned fixed capital assets excluding land

Cost $B_{2}$ : Cost $B_{1}+$ Rental value of own land (net of land revenue) + Rent paid for leased in land

Cost $C_{1}$ : Cost $B_{1}+$ Imputed value of family labour

Cost $C_{2}$ : Cost $B_{2}+$ Imputed value of family labour

Cost $C_{3}$ : Cost $C_{2}+10$ percent of cost $C_{2}$ on account of managerial function performed by the farmer.

\section{Income measures}

For working out profitability of vegetable cultivation in the study areas following income measures were worked out:

(a) Family labour income (FLI)

It is the return to family labour (including management).

F.L.I. $=$ Gross income - Cost $\mathrm{B}_{2}$

(b) Net income (NI)

It is the net profit after deducting all cost items i.e., variable and fixed costs from gross income.

$\mathrm{NI}=$ Gross income - Total $\operatorname{cost}\left(\operatorname{Cost} \mathrm{C}_{3}\right)$ 


\section{(c) Farm business income (FBI)}

It is the disposal income out of the enterprise and is defined as:

$\mathrm{FBI}=$ Gross income - Cost $\mathrm{A}_{1}\left(\operatorname{cost} \mathrm{A}_{2}\right.$ in case of tenant operated land)

(d) Farm Investment Income (FII)

FII $=$ Farm Business Income - Family Labour wages

\section{Definitions of terms and cost concepts used:}

- Fixed cost: The various items viz., land rent, land revenue, depreciation and interest on equipment investment, interest on owned fixed cost, which were used in the vegetable cultivation.

- Variable cost: Variable cost includes the expenditure on labour and material input cost and interest on working capital.

- Inputs and costs: Following were the various inputs used in the vegetable cultivation.

- Hired human labour cost: Hired human labour was estimated in terms of man days where in 8 hours of work in a day was considered as one man day. The man days were valued at ₹ 300 per man day.

- Planting material cost: The planting material cost was worked out at prevailing market price in the study area.

- Fertilizer cost: The fertilizers cost was calculated at the actual price paid by farmers.

- Plant protection cost: This variable included the expenses incurred on the purchase of insecticides, fungicides, weedicides etc. used for the various vegetable crops.

- Depreciation: The amount of depreciation for implements was calculated by the straight line method i.e., by dividing the original cost less junk value of implement by its expected life. This was apportioned to individual crop proportion to the total cultivated area.

- Land revenue: Actually paid land revenue by the farmers was taken into the study.

- Land rent: Land rent was evaluated at the rate of one fourth of the total produce produced and then converted into monetary units by multiplying it with prevailing farm harvest price.
- Interest on working capital: Interest on fixed and working capital is charged at the rate of 9 per cent per annum for half of the year.

- Interest on fixed capital: Interest on fixed and working capital has been charged at the rate of 9 per cent per annum on the average investment (half of the initial cost).

- Family labour: Family labour cost was calculated on the basis of charges paid to hired labour.

- Gross return: Gross return refers to the total income of the farmers earned from crop and livestock sources.

- Net returns: Return obtained by subtracting the total cost from gross return.

\section{RESULTS AND DISCUSSION}

\section{Economics of Pea Production}

\section{Cost of production}

Farm category wise cost of pea crop was estimated and results have been presented in Table 1 . The overall cost of cultivation of pea was estimated to be ₹ 84699.37 per hectare. The cost of cultivation of pea in case of marginal farms was higher (₹ 94443.52) as compared to large farms (₹ 68004.39). It was ₹ 73632.04 on medium farms and ₹ 79941.99 on small farms.

Among different input operation on overall level, the per hectare cost was observed highest for FYM (₹ 8988.42) and the cost of owed human labour is the major contributor to the cost of cultivation of pea. The cost A1 in case of large farms was highest $(53.26 \%)$ as compared to marginal farms (51.76 \%), medium farms (52.05\%) and small farms (52.60\%). There is no cost A2 because farmers used their owed land for cultivation of capsicum. Similar trend was found in cost B1 and cost B2 as in cost A1.The cost $\mathrm{C} 1$ in case of marginal farms was found highest $(81.30 \%)$ as compared to large farms $(78.72 \%)$, medium farms (79.80 \%), and small farms (80.47\%). The cost C3 in case of marginal farms was higher (₹ 128959.10) as compared to large farms (₹ 101657.19), medium farms (₹ 111533.48) and small farms (₹ 118695.63). 
Table 1: Farm Category wise Cost of Pea under in Sampled Vegetable Growers (₹/ha)

\begin{tabular}{|c|c|c|c|c|c|c|}
\hline Sl. No. & Particulars & Marginal & Small & Medium & Large & Overall \\
\hline \multirow{14}{*}{1} & Cost A1 & & & & & \\
\hline & Human hired labour & 6200.00 & 7538.46 & 7916.67 & 8808.14 & 7679.54 \\
\hline & Owned machinery labour & 133.33 & 1461.54 & 972.22 & 1308.14 & 978.76 \\
\hline & Hired machinery labour & 3000.00 & 341.88 & 694.44 & 872.09 & 1196.91 \\
\hline & Seed/plants & 6275.83 & 5957.26 & 5666.67 & 5337.21 & 5792.47 \\
\hline & FYM & 16100.00 & 7589.74 & 6750.00 & 6279.07 & 8988.42 \\
\hline & Fertilizer & 3726.13 & 3341.95 & 3044.17 & 2932.15 & 3243.18 \\
\hline & Plant protection & 5000.00 & 4991.45 & 5000.00 & 5000.00 & 5003.86 \\
\hline & Staking & 1500.00 & 1497.44 & 1500.00 & 1500.00 & 1501.16 \\
\hline & Packaging & 319.33 & 317.26 & 305.56 & 297.67 & 309.65 \\
\hline & Depreciation & 6094.11 & 8593.01 & 6070.43 & 3477.85 & 5580.56 \\
\hline & Land Revenue & 6.00 & 6.00 & 6.00 & 6.00 & 6.00 \\
\hline & Interest on working capital & 528.18 & 412.96 & 398.12 & 404.18 & 433.67 \\
\hline & Sub-total & $\begin{array}{l}48882.93 \\
(51.76)\end{array}$ & $\begin{array}{l}42048.97 \\
(52.60)\end{array}$ & $\begin{array}{l}38324.27 \\
(52.05)\end{array}$ & $\begin{array}{l}36222.50 \\
(53.26)\end{array}$ & $\begin{array}{l}4150.67 \\
(52.13)\end{array}$ \\
\hline \multirow[t]{4}{*}{2} & Cost A2 & & & & & \\
\hline & Cost A1 & 48882.93 & 42048.97 & 38324.27 & 36222.50 & 44150.67 \\
\hline & Rental value of leased -in land & 0.00 & 0.00 & 0.00 & 0.00 & 0.00 \\
\hline & Sub-total & $\begin{array}{l}48882.93 \\
(51.76) \\
\end{array}$ & $\begin{array}{l}42048.97 \\
(52.60)\end{array}$ & $\begin{array}{l}38324.27 \\
(52.05)\end{array}$ & $\begin{array}{l}36222.50 \\
(53.26)\end{array}$ & $\begin{array}{l}44150.67 \\
(52.13) \\
\end{array}$ \\
\hline \multirow[t]{4}{*}{3} & Cost B1 & & & & & \\
\hline & Cost A1 & 48882.93 & 42048.97 & 38324.27 & 36222.50 & 44150.67 \\
\hline & Interest on Fixed capital & 838.78 & 1419.02 & 977.91 & 568.28 & 937.63 \\
\hline & Sub-total & $\begin{array}{l}49721.71 \\
(52.65)\end{array}$ & $\begin{array}{l}43467.99 \\
(54.37)\end{array}$ & $\begin{array}{l}39302.18 \\
(53.38)\end{array}$ & $\begin{array}{l}36790.79 \\
(54.10)\end{array}$ & $\begin{array}{l}45135.52 \\
(53.29)\end{array}$ \\
\hline \multirow[t]{5}{*}{$\overline{4}$} & Cost B2 & & & & & \\
\hline & Cost B1 & 49721.71 & 43467.99 & 39302.18 & 36790.79 & 45135.52 \\
\hline & Rental value of land & 12386.03 & 12386.03 & 12386.03 & 12386.03 & 12386.03 \\
\hline & Rental value of leased -in land & 0.00 & 0.00 & 0.00 & 0.00 & 0.00 \\
\hline & Sub-total & $\begin{array}{l}62107.74 \\
(65.76) \\
\end{array}$ & $\begin{array}{l}55854.02 \\
(69.87)\end{array}$ & $\begin{array}{l}51688.22 \\
(70.20)\end{array}$ & $\begin{array}{l}49176.82 \\
(72.31)\end{array}$ & $\begin{array}{l}57521.56 \\
(67.91)\end{array}$ \\
\hline \multirow[t]{4}{*}{5} & Cost $\mathrm{C} 1$ & & & & & \\
\hline & Cost B1 & 49721.71 & 43467.99 & 39302.18 & 36790.79 & 45135.52 \\
\hline & Imputed value of family labour & 23750.00 & 16820.51 & 15250.00 & 12645.35 & 16899.61 \\
\hline & Sub-total & $\begin{array}{l}73471.71 \\
(77.79) \\
\end{array}$ & $\begin{array}{l}60288.50 \\
(75.42) \\
\end{array}$ & $\begin{array}{l}54552.18 \\
(74.09) \\
\end{array}$ & $\begin{array}{l}49436.13 \\
(72.70) \\
\end{array}$ & $\begin{array}{l}64613.39 \\
(76.29) \\
\end{array}$ \\
\hline \multirow[t]{4}{*}{6} & Cost C2 & & & & & \\
\hline & Cost B2 & 62107.74 & 55854.02 & 51688.22 & 49176.82 & 57521.56 \\
\hline & Imputed value of family labour & 23750.00 & 16820.51 & 15250.00 & 12645.35 & 16899.61 \\
\hline & Sub-total & $\begin{array}{l}85857.74 \\
(90.91)\end{array}$ & $\begin{array}{l}72674.53 \\
(90.91)\end{array}$ & $\begin{array}{l}\mathbf{6 6 9 3 8 . 2 2} \\
(90.91)\end{array}$ & $\begin{array}{l}\text { 61822.17 } \\
(90.91)\end{array}$ & $\begin{array}{l}76999.43 \\
(90.91)\end{array}$ \\
\hline \multirow[t]{4}{*}{7} & Cost C3 & & & & & \\
\hline & Cost C2 & 85857.74 & 72674.53 & 66938.22 & 61822.17 & 76999.43 \\
\hline & Value of management input $(10 \%$ of cost $\mathrm{C} 2)$ & 8585.77 & 7267.45 & 6693.82 & 6182.22 & 7699.94 \\
\hline & Sub-total & $\begin{array}{l}94443.52 \\
(100.00)\end{array}$ & $\begin{array}{l}79941.99 \\
(100.00)\end{array}$ & $\begin{array}{l}73632.04 \\
(100.00)\end{array}$ & $\begin{array}{l}68004.39 \\
(100.00)\end{array}$ & $\begin{array}{l}84699.37 \\
(100.00)\end{array}$ \\
\hline
\end{tabular}

\section{Returns from pea under open field conditions}

The information regarding the returns from pea per hectare basis is given in the table 2 . The results revealed that on an overall basis, yield of pea was 72.16 quintals per hectare. The yield of pea was highest (79.83 qtls.) on marginal farms followed by medium farms. farms (76.39 qtls.), large farms (74.42 qtls.) and small farms (56.07 qtls.) which indicated that gross return were found higher in marginal farms as compared to small, medium and large farms. It may due to better management practices and efficient use of resources by marginal farmers. 
Table 2: Farm Category wise Return from Pea in Sampled Vegetable Growers (₹/ha.)

\begin{tabular}{|c|c|c|c|c|c|c|}
\hline Sl. No. & Particulars & Marginal & Small & Medium & Large & Overall \\
\hline 1 & Yield of Pea (q) & 79.83 & 56.07 & 76.39 & 74.42 & 72.16 \\
\hline 2 & Gross Return & 159666.67 & 112136.75 & 152777.78 & 148837.21 & 144324.32 \\
\hline 3 & $\begin{array}{l}\text { Farm Business Income } \\
\text { (Gross return- Cost A1) }\end{array}$ & 110783.74 & 70087.79 & 114453.51 & 112614.71 & 100173.66 \\
\hline 4 & $\begin{array}{l}\text { Family Labour income } \\
\text { (Gross return - Cost B2) }\end{array}$ & 97558.92 & 56282.73 & 101089.56 & 99660.39 & 86802.77 \\
\hline 5 & $\begin{array}{l}\text { Farm Income (net income) } \\
\text { (Gross return - Cost C } 3 \text { ) }\end{array}$ & 65223.15 & 32194.76 & 79145.74 & 80832.82 & 59624.95 \\
\hline 6 & $\begin{array}{l}\text { Farm Investment Income } \\
\text { (Farm Business Income - Family Labour } \\
\text { wages) }\end{array}$ & 87033.74 & 53267.27 & 99203.51 & 99969.36 & 83274.04 \\
\hline
\end{tabular}

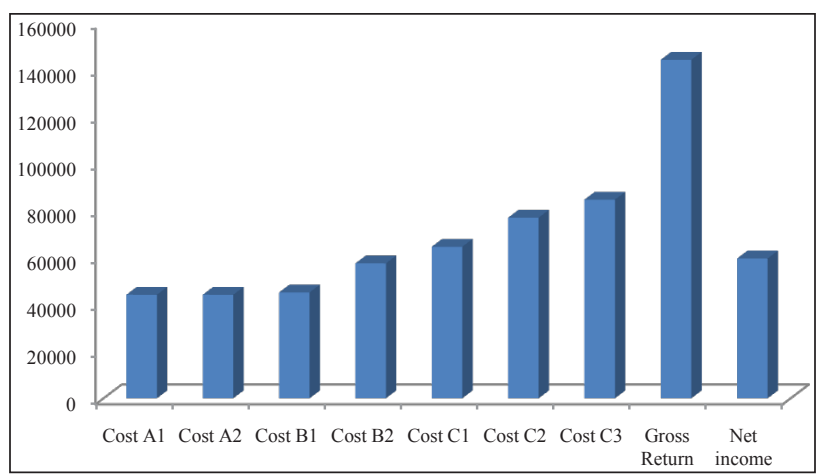

Fig. 1: Economics of Pea crop per ha in Himachal Pradesh

\section{CONCLUSIONS}

The total cost of cultivation was found ₹ 84699.37 per hectare in pea cultivation. The Cost A1 of pea recorded ₹ 44150.67 per hectare which contributes $52.13 \%$ of the cost C3. The yield of green peas has been higher on marginal farms than medium and large farms because of better management in small farms. The gross and net returns have been found higher in large farms due to realization of higher prices because of cultivating early-maturing varieties and exploring other markets due to higher marketable surpluses. This crop, being highly labour-intensive, will help provide employment to the family members on the farm itself, particularly in the case of small and marginal farmers. It will provide impetus to the diversification programme of the state government, besides improving the soil health, being a leguminous crop. Improved variety seeds are of higher unit price and provide high productivity and return, therefore, to be used as per capacity of the growers. Bank credit and financial assistance should be available to the individual farmers for increasing the production. Training of farmers in the areas of production technology, grading, standardization of produce, quality control and modern method of marketing will prove to be a viable move. The government should establish adequate storages at village level for the purpose of orderly marketing of green pea to benefit both consumers and producers.

\section{REFERENCES}

Anonymous, 2018. National Horticulture Board, New Delhi. Khunt, K.A. and Desai, D.B. 1996. Economic feasibility and marketing of perennial vegetables in South Gujarat. Financing Agriculture, 28: 9-14.

Maurya, O.P., Singh, G.N. and Kushwaha, R.K.S. 2001. An economic analysis of production and marketing of potato in district Varanasi (UP). In: Encyclopaedia of Agricultural Marketing, Vol. 8, Ed : J. Prasad. New Delhi: Mittal Publications, pp. 229-38.

Oelke, E.A., Oplinger, E.S., Hanson, C.V., Davis, D.W., Putnam, D.H., Fuller, E.I. and Rosen, C.J. 1991. Dry Field Pea. University of Wisconsin.

Rao, N.S. and Tripathi, B.N. 1979. A study of economics of production and marketing of some vegetable crops in Kankipadu block of Krishna District, AP. Allahabad Farmer, 50: 341.

Singla Rohit, Chahal, S.S. and Kataria, P. 2006. Economics of Production of Green Peas (Pisum sativum L.) in Punjab. Agricultural Economics Research Review, 19: 237-250.

Sharma, B.K. 2003. Per capita availability of vegetables, The Indian Express (Chandigarh), August 20, 27: 11.

Sharma, V.K., Inder Sain and Singh, G. 2000. Income and employment from summer vegetables vis-à-vis paddy in Punjab. Journal of Agriculture Development $\mathcal{E}$ Policy, 12: 38-43.

Swaminathan, M.S. 2002. Food groups and balance diet: Recommended dietary allowances. In: Essentials of Food and Nutrition - An Advanced Textbook, Vol. 2, pp. 1-23. Bangalore: The Bangalore Printing and Publishing Co. Ltd.

Thakur, D.S., Sanjay, Thakur, D.R. and Sharma, K.D. 1994. Economics of off-season vegetable production and marketing in hills. Indian Journal of Agricultural Marketing, 8: 72-82. 
